\title{
EPHB1 wt Allele
}

National Cancer Institute

\section{Source}

National Cancer Institute. EPHB1 wt Allele. NCI Thesaurus. Code C52163.

Human EPHB1 wild-type allele is located within 3q21-q23 and is approximately $464 \mathrm{~kb}$ in length. This allele, which encodes ephrin type-B receptor 1 protein is involved in developmental processes and may play a role in neurogenesis. 